\title{
SCIENCE PRACTICAL WORK AND ITS IMPACT ON STUDENTS' SCIENCE ACHIEVEMENT
}

\author{
Zuhrieh Shana iD, Enas S. Abulibdeh iD \\ Al Ain University (United Arab Emirates) \\ zoeshanaa@yahoo.com,enas.abulibdeb@gmail.com
}

Received December 2019

Accepted July 2020

\section{Abstract}

The purpose of this quasi-experimental study is to evaluate the overall effect of practical work on students' academic attainment in science. Participants were selected from tenth grade students (chemistry and biology) and eleventh grade students (chemistry), then divided into groups. The control groups were taught using traditional methods of teaching science, while the same content was given to the experimental groups using intensive practical work. Pre and post-tests were given to all groups. The mean score comparison revealed a significant difference in the attainment scores of the experimental over the control groups. It is thus recommended that students be given ample opportunity to be engaged in practical lessons in secondary schools. This entails that the administration of schools supplies their labs with all equipment needed for practical work to be effectively implemented

Keywords - Science process skills, Practical work, Science concept, Science instruction.

\section{To cite this article:}

Sshana, Z.J., \& Abulibdeh, E.S. (2020). Science practical work and its impact on students' science achievement. Journal of Technology and Science Education, 10(2), 199-215. https://doi.org/10.3926/jotse.888

\section{Introduction}

From the beginning of the 18th century to date, educators and researchers have studied the value of practical work and its important role in scientific fields such as chemistry and biology. Multiple studies showed that practical work confers many advantages, including developing laboratory skills and scientific knowledge, as well as understanding science concepts and theories (Fadzil \& Saat, 2013; Schwichow, Zimmerman, Croker \& Härtig, 2016). In support of practical work in the scientific fields, Roberts (2008) designed a booklet on high quality practical activities in science, in which she stated: "Students achieve a deeper level of understanding by finding things out for themselves and by experimenting with techniques and methods that have enabled the secrets of our bodies, our environment, and the whole universe - to be discovered."

Practical work has been able to promote students' positive attitudes and enhance motivation for effective learning in science as described by Okam and Zakari (2017). Consequently, a positive attitude toward the importance of practical work meaningfully affects students' achievement in science (Hinneh, 2017). 
Practical work has also been shown in some studies to help improve the communication skills of students in order to solve problems in science and thus become more motivated in science (Woolnough, 1994). In addition to this, practical work encourages and increases students' interest in science and promotes it as an engaging subject. As an example, when students practice chemical reactions, they see that chemistry/science is an applied science and not just theories and rules.

Laboratory work plays a significant role in science education (Hofstein \& Lunetta, 1982; Hofstein \& Mamlok-Naaman, 2007). In the educational process, laboratories can be used to develop scientific notations and create models to test hypotheses. Laboratory work also helps in understanding the difference between observation and presentation of data (Lawson, 1995). In support of this fact, it is documented that "Laboratory activities appeal as a way of allowing students to learn with understanding and, at the same time, engage in a process of constructing knowledge by doing science" (Tobin, 1990). Laboratory experiments have vital importance in the study of all scientific subjects (chemistry, physics, and biology).

A contrasting view to the advantages of laboratory-based teaching has been posed by Abrahams and Millar (2008). They state some disadvantages of laboratory-based teaching as being an inefficient teaching method and cannot represent scientific inquiry properly, rather this should be taught through direct lecturing. Also, Hodson (1990) claimed that practical work may be applied in a way where students only follow the instructions given by the teacher and which means they do not need to use creativity or cognitive thinking to process the information. Thus practical work is a waste of time, confusing and counter-productive (Hodson, 1990).

In light of the United Arab Emirates (UAE) 2021 vision to progress as a nation and invest in its youth in hopes of becoming amongst the highest ranks in the world in reading, mathematics and science, the country has recently made major developments in the education system (UAE Vision 2021, n.d). In an effort to work towards achieving the vision, the emirate of Abu Dhabi in particular has recently made drastic changes in its education system in terms of teacher qualifications and classroom practices (McKnight, Yarbro, Graybeal \& Graybeal, 2016) while placing an emphasis on developing 21st century skills and preparing students to enter the modern market.

The teaching and learning process is a complex one that involves many aspects, which contribute to its success. One of these aspects is the method of delivery and practices used in the classroom by the instructor. The focus of our study is to highlight the importance of combining theoretical and practical work in the educational process, specifically in the field of Science.

In UAE public and private schools, boys and girls are instructed separately in segregated classes in all grades. Thus, the selection of the participant/classes to include in the study was based on availability of the students and the willingness of teachers to cooperate in collecting our data.

Having said that, this research shines a light on teaching practices used inside the classroom, specifically those of grade 10 and 11 female students within two private schools in the city of Abu Dhabi, UAE.

The findings of the research may be useful in assisting teachers all over the UAE in designing and planning their lessons to achieve the highest potential of teaching and learning science.

\subsection{Research Questions}

Consequently, the current study will be guided by the following main research questions:

Consequently, the current study will be guided by the following research questions:

(1) Is there any statistical difference between the academic attainment of students taught science using practical activity and those taught using traditional expository/lecture? 
(2) Is there any statistical difference between the academic attainment of chemistry and biology students taught using practical activities?

(3) Is there any statistical difference between the academic attainment of chemistry and biology students taught using traditional expository/lecture?

As a tentative answer for these research questions, the following null hypotheses were raised and tested at . 05 level of significance.

(1) There is no significant difference between the academic attainment of science students taught using practical activities and those taught using traditional expository/lecture.

(2) There is no significant difference between the academic attainment of chemistry and biology students taught using practical activities.

(3) There is no significant difference between the academic attainment of chemistry and biology taught using traditional expository/lecture

\section{Literature Review}

Education around the world has developed from a teacher-centered learning transforming into a studentcentered learning that teaches students how to take responsibility for their own learning and become more independent. Many teachers still follow traditional practices such as direct lecturing, strict use of textbook as the only reference, and rarely extend their teaching to make it relevant to real-life scenarios. As stated by Yore (2001), this does not place any importance on the development of critical thinking skills and whole concepts that are important to science literacy. On the other hand, Cobb, McClain, de Silva Lamberg and Dean (2003) state that: "Design experiments have both a pragmatic bent and a theoretical orientation developing domain-specific theories by systematically studying those forms of learning and the means of supporting them."

The goals of practical work are to improve students' understanding, develop their skills in solving problems and understanding the nature of science, by replicating the actions of scientists. Sotiriou, Bybee and Bogner (2017) state that: "While solving a scientific problem, students should act like a scientist and follow scientific processes." According to Hodson (1990), practical work can motivate students, stimulate their interest in teaching and learning, enhance the learning of scientific knowledge, give them experience in using scientific knowledge and widen their way of thinking.

Tsakeni (2018) explored access to effective practical work for physical sciences learners in two South African high school schools. The results revealed that the absence of practical examinations resulted in underestimating practical work in physical sciences classrooms, and thus marginalised learners. Tsakeni indicated that the limited access led to a social justice agenda due to the high expectations linked to studying physical sciences. Tsakeni recommended supporting practical work through the processes of assessment and tools for instructional leadership.

According to Dillon (2008), there are many reasons for doing practical work for scientific subjects in schools. Some of the reasons are to encourage accurate observations and descriptions, to change theories into real-life application, to keep the interest of students in scientific studies and promote a logical and reasoning method of thought. As well, Bryson, Millar, Joseph and Mobolurin (2002) argue that practical work helps to improve students' scientific knowledge.

\subsection{Effectiveness of Practical Work}

It is widely argued that practical work is essential to teaching and learning in the field of scientific studies and that good quality practical work helps develop students' understanding of scientific processes and concepts (Jakeways, 1986). However, whether this has an effect on the attainment scores of the students is still under investigation. 
In a study conducted over a duration of eight weeks on a group of 40 students from grade 5 , from two different classes selected through purposive sampling, it was shown that students who were instructed through inquiry-based learning achieved higher scores than the ones who were instructed through traditional methods (Abdi, 2014).

Several studies examining the role of practical work on student attainment investigated many aspects of the quality of the practical work, such as the design of the task given in terms of encouraging students to make links between the theoretical and practical sides.

In a study done on a sample of 25 science lessons involving practical work in English secondary schools, the results showed that the practical work supported the direction of the lesson in that it kept students focused on tasks and doing the hands-on work. However, practical work was proven less effective in getting those students to make a connection between concept and application in the lab and reflect on their collected data (Abrahams \& Millar, 2008). The study found that there was insufficient proof that linking concepts to observables is taken into consideration by the people who design these activities for the science lessons.

Millar (2004) proposes that students' minds should be stimulated prior to starting any practical work by providing them with some background information on what it is they are investigating. Also, the task design should direct students' efforts to make links between the two domains of knowledge. Consequently, science teachers should be trained based on the most recent research studies to amend their practices and put forth more time and effort to reflect on linking scientific concepts with the natural world (Jokiranta, 2014).

However, one should keep in mind that the feedback from teachers of laboratory work is a vital source of information about its value. In previous studies, they mentioned that laboratory work is vital for studying sciences but there are certain problems they faced such as: lack of materials needed for the required experiments, insufficient information for carrying out the experiment, insufficient techniques followed during the experiment, lack of information about the glassware and the chemicals that are needed for the experiment, lack of information about safety rules, lack of information about the steps that should be followed to avoid any accident during the experiment and finally what should be done in case of an accident during the experiment (Aydogdu, 2015; Boyuk, Demir \& Erol, 2010).

\subsection{Cons of Practical Work}

On the other hand, Sotiriou, Bybee and Bogner (2017) mentioned that traditional lab work focuses solely on scientific terminology and allows students to see only what is happening during experiments; in addition, students may follow instructions written in the lab manual step by step which will not give students the chance for creativity and cannot develop their cognitive skills. If students simply follow the lab manual during experiments without connecting it to real life, then the methods will be of no value. According to Madhuri, Kantamreddi, and Prakash Goteti (2012), "the most important negation of cookbook style laboratory is it doesn't help students translate scientific outcomes into meaningful learning."

Some teachers show doubts regarding the effectiveness of practical work in teaching scientific knowledge. For example, Hodson (1991) states that: "As practiced in many schools, it [practical work] is ill-conceived, confused and unproductive. For many children, what goes on in the laboratory contributes little to their learning of science... At the root of the problem is the unthinking use of laboratory work."

Some learners show similar doubts about the effectiveness of practical work in students' learning of science, as was found by Woolnough and Allsop (1985) and Osborne (1993). The reason for such criticisms by these learners is that practical work is ineffective for learning a concept or a theory. According to Millar (2004), one important condition for the success of inquiry-based learning is that the learning objectives should be clear, concise and easy to follow by the learners. 
Solomon (1999) mentions a scenario where a student in the medical field is exposed to his first X-ray picture and cannot make sense of it. Lecture alone, without seeing an X-ray picture, made it difficult for him to comprehend the results. When finally combining both the theoretical and the practical, everything made more sense to the student. Thus, it can be concluded that in the scientific field practical and theoretical delivery are intertwined and cannot be separated.

\subsection{Practical Work in Chemistry and Biology}

The subjects of chemistry and biology are important fields of science that examine the structure of matter, composition, properties, and the interaction between elements. They enable learners to understand what happens around them. But generally, they are considered difficult subjects to learn due to the great amount of information needed about materials and their properties, which might discourage learners from studying these subjects. To understand the properties of all materials and the changes that take place when they interact, many practical applications and experiments must take place in the course of studying these two challenging subjects.

Although laboratory work is a core component in the subjects of chemistry and biology, some previous researches argue that:

(1) Conventional laboratory work or activities fail to engage students in discussions and do not promote the development of the skills needed to understand chemistry effectively (Hofstein \& Lunetta, 1982; Singer, Hilton \& Schweingruber, 2006).

(2) If laboratory experimental work is applied traditionally, then only small groups of students will be involved in this work (Singer et al., 2006).

(3) Students' discussion during the laboratory work is mainly centered on the procedures needed to carry out the experiment or how to manage lab equipment (Russell \& Weaver, 2011; Sandi-Urena, Cooper, Gatlin, \& Bhattacharyya, 2011).

When it comes to group work in experimental activities in chemistry and biology, the kind of interaction between the members of the group will influence the quality of the group work and level of understanding the experiment, and to some extent the expected outcomes. During group work experiments, it is important that every student has the opportunity to apply what he/she has learned to future tasks to improve his/her learning (Russell \& Weaver, 2011; Sandi-Urena et al., 2011)

According to Piaget (2013), people construct increasingly sophisticated and powerful representations of the world by acting on them in the light of current understanding. If one considers that Piaget is correct, then practical work is important in understanding sciences in general. The main role of practical work is to give support for students in their learning and to make a link between the domain of real objects and observable facts on one hand and the domain of ideas on the other (Bryson et al., 2002).

\subsection{Methods of Teaching, Learning, and Assessment}

Numerous diverse methods of teaching, learning and assessment are used in teaching science curriculum in UAE high schools. According to Edgar Dale's Cone of Experience (Dale, 1969) shown in Figure 1 below, people learn, retain and remember $10 \%$ of what they read, $20 \%$ of what they hear, $30 \%$ of what they see, $50 \%$ of what they see and hear, $70 \%$ of what they say and write, and $90 \%$ of what they say as they do a thing.

Based on Dale's Cone, the least effective methods of learning involve learning from information presented through written and verbal symbols, i.e., reading and hearing, while the most effective methods involve direct, purposeful learning experiences, such as hands-on or field experience (Anderson, n.d). The experiences in each stage can be mixed and are interrelated that fosters more meaningful learning. Direct purposeful experiences represent reality or the closest things to everyday life (ibid). Dale's Cone of 
Experience suggests that when choosing an instructional method it is important to involve students in the process in order to maximize their information retention.

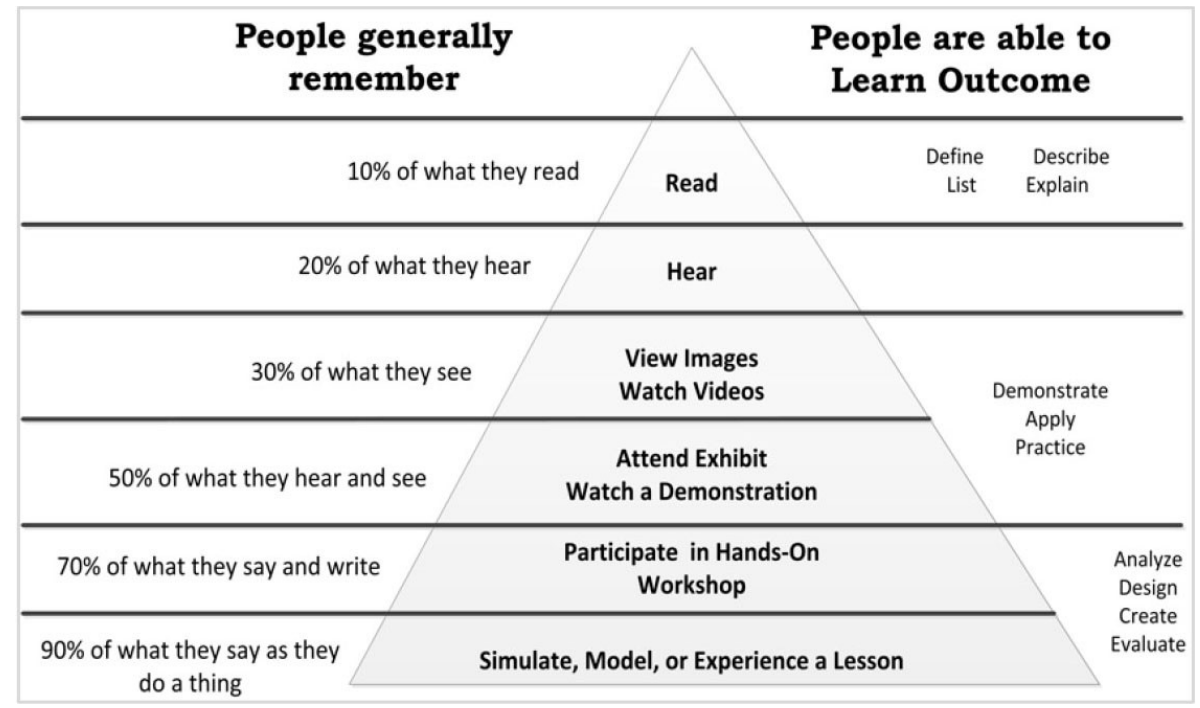

Figure 1. Edgar Dale Cone of Experience (Dale, 1969)

According to the above-suggested facts and to keep the class energy elevated, in-class activities/projects are mainly done in small groups. As a starting step in this direction, specific techniques and ideas are offered through demonstrations and hands-on experiences of the lesson core skills of the assigned projects. Consequently, and in order to simulate "doing the real thing" and to maximize chances to share what they know and do, group members are encouraged to articulate and represent what they know and are able to do through the process of demonstrating and explaining them to others. This practical technique aims to help reinforce lesson concepts and encourage students to take ownership of the learning. As a result, this will help students make connections to the lessons learned in the classroom.

This study seeks to make a contribution to the teaching and learning process of science subjects such as chemistry and biology by shedding light on students' engagement as an essential aspect of the teaching and learning process. Science fields should have their purposes made explicit to students if they are to benefit fully from them. Otherwise students would see practical work merely as a break from the routine activities of speaking, listening and writing. Therefore, hands-on learning is key to the development of students' knowledge and skills through the tying of practical and theory together. Adopting practical work is useful for teachers in local UAE schools as it would help them in teaching various topics in the science curriculum by engaging students in the learning process. Many schools could also enhance their science curriculum through provision of practical work along with the provision of theoretical knowledge using traditional teaching methods.

\section{Methodology}

\subsection{Research Design}

The quasi-experimental research design was used. Quasi-experiment research is conducted in field settings in which random assignment is impossible or absent, and is often conducted to evaluate the effectiveness of a treatment or an educational intervention (Price, Jhangiani \& Chiang, 2015; White \& Sabarwal, 2014).

The participants were divided into control and experimental groups for chemistry and biology subjects. A pre-test and post-test instrument was adopted to assess the effect of practical work on high school students' understanding of science (Campbell \& Stanley, 1963). The chemistry group was divided into two 
sub-groups (grade 10 and grade 11), while the biology group consisted of one group of grade 10 students. The experimental group and the control group consisted of 49 students each.

Prior to dividing the students into control and experimental groups, all participating students were pre-tested to determine their level of science content understanding. This was done to ensure similarity/homogeneity of the two groups before starting the intervention, thus students in both control and experimental groups had the same academic level and pre-test scores. For a period of three weeks, the control group students (chemistry and biology) were taught using the conventional method while the experimental group students (chemistry and biology) were taught using the intensive practical method (the intervention), as shown in Table 1. Thus, for the experimental group, all the teaching hours were taught in the laboratory.

After the intervention was completed, the post-test was conducted to measure the students' attainment. The data was collected and statistically analysed to explore any significant differences in the attainment mean scores of the control and experimental groups. Table 2 illustrates the study design.

\begin{tabular}{|l|l|l|}
\hline$\#$ & Traditional Way of Teaching & Modern/Practical Method of Teaching \\
\hline 1 & Relies mainly on textbooks & Relies on hands-on materials approach \\
\hline 2 & Presentation of materials is from parts to the whole & Presentation of materials is from whole to parts \\
\hline 3 & Assessment is a separate activity & Assessment is an integrated activity \\
\hline 4 & Emphasis on basic skills & Emphasis on big ideas \\
\hline 5 & Testing is the major mean of assessment & $\begin{array}{l}\text { Portfolios and observation are major means of } \\
\text { assessment (Brooks \& Brooks, 1999) }\end{array}$ \\
\hline 6 & Use homeroom for the science instruction & Use another classroom/lab for Science Instruction \\
\hline
\end{tabular}

Table 1. Traditional Verses Modern/Hands-On Approaches in Teaching Science

\begin{tabular}{|c|c|c|}
\hline Group & Control Group & Experimental Group \\
\hline Pre-Test & $\begin{array}{c}\text { Ability regarding science content } \\
\text { understanding }\end{array}$ & $\begin{array}{c}\text { Ability regarding science content } \\
\text { understanding }\end{array}$ \\
\hline Duration & Three weeks & Three weeks \\
\hline Post-Test & $\begin{array}{c}\text { Change in ability regarding science content } \\
\text { understanding }\end{array}$ & $\begin{array}{c}\text { Change in ability regarding science content } \\
\text { understanding }\end{array}$ \\
\hline
\end{tabular}

Table 2. The Pre-Test and Post-Test design for both groups

\subsection{Study Sample}

The purpose of this study was to evaluate the overall effect of practical work on students' academic attainment in science, specifically Chemistry and Biology, in two private schools in Abu Dhabi. The purposively selected schools are Al Dhafra Private School (grade 10 biology and grade 11 chemistry class) and Sheikh Zayed Private Academy (grade 10 chemistry class). Table 3 illustrates the study sample. The students were selected randomly from the selected classes (grades 10 and 11) ensuring that they had similar academic attainment level.

\begin{tabular}{|c|c|c|c|c|}
\hline Groups & $\begin{array}{l}\text { Chemistry } \\
\text { (Grade 11) }\end{array}$ & $\begin{array}{l}\text { Chemistry } \\
\text { (Grade 10) }\end{array}$ & $\begin{array}{c}\text { Biology } \\
\text { (Grade 10) }\end{array}$ & Total \\
\hline Control Group & 13 & 22 & 14 & 49 \\
\hline Experimental Group & 13 & 22 & 14 & 49 \\
\hline
\end{tabular}

Table 3. Study Sample distribution 


\subsection{Instrument}

In this quasi-experimental study, the independent variable was the practical work undertaken by students in the school's laboratory, and the dependent variable was the academic attainment of the participants. All variables were the same (allocated time, curriculum content, activities and tests ...etc.) the only manipulated variable is the independent variable. The two different groups (control \& experimental) were treated as two sections for the same class. They were allocated the same number of teaching hours on the weekly teaching schedule. On the other hand, both groups were considered and dealt with as if they are members of the same class. Consequently, all groups received identical class content and hand-outs, same teaching hours and by the same teachers. The controlled group students were taught by the conventional/traditional teaching method which is "when students learn through memorization and recitation techniques thereby not developing their critical thinking problem solving and decision-making skills" (Sunal, Smith, Sunal \& Britt, 1998). On the other hand, the experimental group students were taught the same exact curriculum by using the modern/practical teaching technique, which can be defined as "the intentional process of diagnosing problems, critiquing experiments, and distinguishing alternatives, planning investigations, researching conjectures, searching for information, constructing models, debating with peers, and forming coherent arguments" (Linn, Davis \& Bell, 2004).

To measure the dependent variable, a test was administered prior to participating in the scientific practical activities (pre-test), and after the completion of the activities (post-test). Then a comparison between the pre-test and post-test scores was done to assess the effectiveness of the intervention (practical activities). The gained scores were of concern to the researchers as an indicator of the gained knowledge, reflected in obtained figures. To achieve such a target, each grade had its own experiment with pre-test and post-test based on the curriculum and subject (chemistry or biology) as follows:

\subsubsection{Experiment No. 1: Chemistry / Acid-Base Titration}

The chemistry unit topic "Acid-Base Titration" aims to cover, illustrate and explain:

That titration is the slow addition of one solution of a known concentration to a known volume of another solution of unknown concentration until the reaction reaches completion. In a broad sense, it is a technique to determine the concentration of an unknown solution. In this chemistry lesson, students explain the difference between acids and bases. They discuss the role of indicators in titration.

This topic was discussed and taught in the conventional method of teaching (Birk \& Foster, 1993) to the control group using:

- Texts and problems orientation

- Question formulation

- Lecture attendance

- Discussion monitoring

- Questions and objective type questions: writing and replying

- Problem solving

- Oral presentation of answers

As for the experimental group, although they provide the exact content, the students were taken to the chemistry lab and were provided with glassware, sulphuric acid, and sodium hydroxide. After designing the experiment, students were asked to carry out the monitored experiments to generate answers to the intended questions.

The students' performance in chemistry was determined by scores obtained by students subjected to the test composed of the seven questions related to acid-base titration and recording their results as a pre-test, then comparing these results to the ones recorded in the post-test for the same questions as shown in Table 4. 


\begin{tabular}{|c|c|}
\hline \# & The Pre-Test/Post-Test Questions \\
\hline & Please read and answer each question carefully (Q1 to Q7): \\
\hline 1 & Define the term acid-base titration. \\
\hline 2 & $\begin{array}{l}\text { Calculate the volume of hydrochloric acid of concentration } 0.2 \mathrm{M} \text { needed to neutralize } 0.1 \mathrm{M} \text { of calcium } \\
\text { hydroxide of volume } 25 \mathrm{ml} \text {. }\end{array}$ \\
\hline 3 & $\begin{array}{l}\text { Using the volume of the acid, explain what was needed to neutralize the base if the acid is strong or } \\
\text { weak. }\end{array}$ \\
\hline 4 & $\begin{array}{l}\text { Using the calculated value of the volume of hydrochloric acid, calculate the number of moles of this } \\
\text { acid. }\end{array}$ \\
\hline 5 & Calculate the mass of hydrochloric acid in grams. \\
\hline 6 & What is the indicator used in this kind of titration? \\
\hline 7 & $\begin{array}{l}\text { Why do you think that this method is an essential method to calculate the concentration of an unknown } \\
\text { acid or base? }\end{array}$ \\
\hline
\end{tabular}

Table 4. The pre-test and post-test for first group of chemistry.

\subsubsection{Experiment No. 2: Chemistry/Thermodynamics}

Following the same methods and procedure, as discussed in the 1st experiment, students were given a lecture on the heat of reactions. The control group was taught through a teacher-centered lecture, where students see knowledge as something to be transferred to them by the teacher (Zhenhui, 2001).

On the other hand, the same exact topic "endothermic and exothermic reactions" was taught to the experimental group using diagrams and examples. The lesson covered the following:

- In all chemical change, reactants are transformed into products by a chemical reaction.

- Transaction of energy occurs in every/all chemical change.

- It is one of the core features of a chemical reaction.

- Typically, energy transaction happens in the form of heat during chemical reactions.

- In some cases, heat energy is absorbed, while in other cases, heat energy is released.

- If more energy is SUPPLIED than is RELEASED then the reaction is ENDOTHERMIC. A reaction is EXOTHERMIC if more energy is RELEASED than SUPPLIED.

Participants were then assessed via a written test before (pre-test) and after (post-test) the implementation of practical work. The pre- and post-test consist of 10 objective questions with 2 formative questions as shown in Table 5.

\begin{tabular}{|c|c|}
\hline$\#$ & \multicolumn{1}{|c|}{ The Pre-Test/Post Test Questions } \\
\hline 1 & Decide whether each of these reactions is exothermic or endothermic (Q1 to Q4): \\
\hline & When two chemicals mix their temperature rises: \\
a. $\quad$ Exothermic \\
b. $\quad$ Endothermic \\
\hline 2 & A solid burns brightly and releases heat, light and sound: \\
& b. Exothermic \\
& b. $\quad$ Endothermic \\
\hline 3 & A solid burns brightly and releases heat, light and sound: \\
& a. Exothermic \\
& b. Endothermic \\
c. Neither \\
\hline 4 & Two chemicals will only react if you heat them continually: \\
& b. Exothermic \\
& c. $\quad$ Neither \\
\hline
\end{tabular}




\begin{tabular}{|c|c|}
\hline \# & The Pre-Test/Post Test Questions \\
\hline & Please read carefully and choose the correct answer (Q5 to Q10) \\
\hline 5 & $\begin{array}{l}\text { Chemical reactions that absorb heat are called __ reactions. } \\
\text { a. Homogeneous } \\
\text { b. Heterogeneous } \\
\text { c. Exothermic } \\
\text { d. Endothermic }\end{array}$ \\
\hline 6 & $\begin{array}{l}\text { Which of the following terms relates most closely to heat being released during a reaction? } \\
\text { a. Endothermic reaction } \\
\text { b. Product } \\
\text { c. Exothermic reaction } \\
\text { d. Reactant }\end{array}$ \\
\hline 7 & $\begin{array}{l}\text { What kind of reaction involves the absorption of heat, leading to a substance feeling colder to } \\
\text { the surroundings? } \\
\text { a. Reactant } \\
\text { b. Liquid } \\
\text { c. Exothermic reaction } \\
\text { d. Endothermic reaction }\end{array}$ \\
\hline 8 & $\begin{array}{l}\text { Given this equation: } \mathbf{H C l}+\text { energy } \rightarrow \mathbf{H}+\mathbf{C l} \\
\text { How can this equation be described? } \\
\text { a. This reaction is endothermic, and the heat is released. } \\
\text { b. This reaction is exothermic, and the heat is released. } \\
\text { c. This reaction is exothermic, and the heat is absorbed. } \\
\text { d. The reaction is endothermic, and the heat is absorbed. }\end{array}$ \\
\hline 9 & $\begin{array}{l}\text { Three forms of energy are: } \\
\text { a. Chemical, exothermic, and temperature. } \\
\text { b. Chemical, thermal, and electromagnetic. } \\
\text { c. Electrical, nuclear, and temperature. } \\
\text { d. Electrical, mechanical, and endothermic. }\end{array}$ \\
\hline 10 & $\begin{array}{l}\text { The burning of methane is an example of a(n): } \\
\text { a. Catabolic reaction. } \\
\text { b. Biochemical reaction. } \\
\text { c. Anabolic reaction. } \\
\text { d. Exothermic reaction. }\end{array}$ \\
\hline & Please read and answer each question carefully (Q11 to Q 12) \\
\hline 11 & $\begin{array}{l}\text { When carbon and oxygen combine to form carbon dioxide, } \Delta \mathrm{H}=-393.5 \mathrm{~kJ} / \mathrm{mol} \text {. Classify this reaction as } \\
\text { being endothermic or exothermic, and describe the reaction in terms of heat flow. }\end{array}$ \\
\hline 12 & How do you know from an energy profile diagram that a reaction is endothermic? \\
\hline
\end{tabular}

Table 5. The pre- and post-test for second group of chemistry.

\subsubsection{Experiment No. 3: Biology/Photosynthesis}

Through the traditional method, students in the control group were exposed to the needs of photosynthesis as an energy-producing process; light-dependent reactions (photosystem 1 and photosystem 2) and light independent reaction (Calvin cycle).

The lesson covered the following:

- What is Photosynthesis?

- Process

- Equation

- Sites of Photosynthesis

- Factors

- Chlorophyll Structure

- Photosynthetic Pigment

- Importance 
The students were then assessed via a written pre-test and post-test containing 10 questions, including 8 objective questions with 2 formative questions, as shown in Table 6 . The same exact content, and exam, was given to the experimental group after they conducted experiments on the topic.

\begin{tabular}{|c|c|}
\hline \# & The Pre-Test/Post Test Questions \\
\hline & Decide whether each of these reactions is exothermic or endothermic (Q1 to Q8): \\
\hline 1 & $\begin{array}{l}\text { What three things do plants need for the process of photosynthesis? } \\
\text { a. Sunlight, oxygen, and sugar } \\
\text { b. Water, soil, and oxygen } \\
\text { c. Sunlight, carbon dioxide, and water } \\
\text { d. Carbon dioxide, oxygen, and soil } \\
\text { e. Sunlight, soil, and water }\end{array}$ \\
\hline 2 & $\begin{array}{l}\text { If plants breathe in carbon dioxide, what do they breathe out? } \\
\text { a. Nitrogen } \\
\text { b. Oxygen } \\
\text { c. Carbon monoxide } \\
\text { d. Hydrogen } \\
\text { e. Helium }\end{array}$ \\
\hline 3 & $\begin{array}{l}\text { What is the compound that plants use to absorb the energy from light? } \\
\text { a. Carbon Dioxide } \\
\text { b. H2O } \\
\text { c. Nitrogen } \\
\text { d. DNA } \\
\text { e. Chlorophyll }\end{array}$ \\
\hline 4 & $\begin{array}{l}\text { What color is chlorophyll? } \\
\text { a. Red } \\
\text { b. Blue } \\
\text { c. Yellow } \\
\text { d. Green } \\
\text { e. Brown }\end{array}$ \\
\hline 5 & $\begin{array}{l}\text { What is the Calvin Cycle? } \\
\text { a. The second phase of photosynthesis } \\
\text { b. Where energy from sunlight is stored in ATP } \\
\text { c. Another name for the water cycle } \\
\text { d. All of the above } \\
\text { e. None of the Above }\end{array}$ \\
\hline 6 & $\begin{array}{l}\text { In a light-dependent reaction, water and sunlight is needed to make oxygen and } \\
\text { a. carbon dioxide } \\
\text { b. sugar } \\
\text { c. ATP } \\
\text { d. chlorophyll }\end{array}$ \\
\hline 7 & $\begin{array}{l}\text { What are the structures inside plant cells that contain chlorophyll called? } \\
\text { a. Nucleus } \\
\text { b. Ribosomes } \\
\text { c. Chloroplasts } \\
\text { d. Lysosomes } \\
\text { e. Mitochondria }\end{array}$ \\
\hline \multirow[t]{2}{*}{8} & $\begin{array}{l}\text { Which of these substances is an end product of photosynthesis? } \\
\text { a. carbon dioxide } \\
\text { b. chlorophyll } \\
\text { c. carotenoids } \\
\text { d. carbohydrates }\end{array}$ \\
\hline & Please read and answer each question carefully (Q9 to Q10) \\
\hline 9 & Explain the role of water in photosynthesis. \\
\hline 10 & What are the by-products of photosynthesis? And what plant pigments are involved in photosynthesis? \\
\hline
\end{tabular}

Table 6 . The pre- and post-test for the biology group. 
Based on the above data, the core research question- Is there any statistical difference between the academic attainment of students taught science using practical activity and those taught using traditional method of teaching? - will be addressed in this study. For this purpose, data generated from statistically analysing the mean scores of pre-test and post-test were used to answer the research questions.

\section{Results}

Prior to performing ANCOVA analysis, the assumptions of normality, the homogeneity of variances, and the homogeneity of regression slopes were assessed. The normality of residuals assumption was satisfied based on Shapiro-Wilks test $(\mathrm{p}=0.685)$. In examining the assumption of the homogeneity of variances, Levene's test indicated that the variances were equal $(\mathrm{F}=2.037, \mathrm{p}=0.138)$ and hence the assumption is met. Finally, the assumption of homogeneity of regression slopes was tested based on the interaction between the covariate (pre-test score) and both independent variables (method and gender). Results indicated that this assumption was met $(\mathrm{F}=2.826, \mathrm{p}=0.098$ and $\mathrm{F}=0.002, \mathrm{p}=0.961$, respectively).

The illustrated data in Table 7 and Table 8 , is evidence that will be used to answer the research questions and the related null hypotheses that were raised and tested.

\begin{tabular}{|c|c|c|c|c|c|}
\hline Subject & Group & Grade & Mean & Std. Deviation & $\mathbf{N}$ \\
\hline \multirow{4}{*}{ Biology } & Experimental & Gr. 10 & 27.00 & $1, i .272$ & 22 \\
\hline & Control & Gr. 10 & 17.14 & 5.092 & 22 \\
\hline & \multirow{2}{*}{ Total } & Gr. 10 & 22.07 & 6.192 & 44 \\
\hline & & Total & 22.07 & 6.192 & 44 \\
\hline \multirow{9}{*}{ Chemistry } & \multirow{3}{*}{ Experimental } & Gr. 10 & 27.14 & .949 & 14 \\
\hline & & Gr. 11 & 27.08 & 1.038 & 13 \\
\hline & & Total & 27.11 & .974 & 27 \\
\hline & \multirow{3}{*}{ Control } & Gr. 10 & 17.64 & 5.213 & 14 \\
\hline & & Gr. 11 & 16.92 & 4.941 & 13 \\
\hline & & Total & 17.30 & 4.999 & 27 \\
\hline & \multirow{3}{*}{ Total } & Gr. 10 & 22.39 & 6.076 & 28 \\
\hline & & Gr. 11 & 22.00 & 6.248 & 26 \\
\hline & & Total & 22.00 & 6.104 & 54 \\
\hline
\end{tabular}

Table 7. Descriptive Statistics post-test

\begin{tabular}{|l|r|r|r|r|r|r|}
\hline \multicolumn{1}{|c|}{ Source } & $\begin{array}{c}\text { Type III Sum } \\
\text { of Squares }\end{array}$ & $\begin{array}{c}\text { Degree of } \\
\text { Freedom }\end{array}$ & \multicolumn{1}{c|}{$\begin{array}{c}\text { Mean } \\
\text { Square }\end{array}$} & $\begin{array}{c}\text { F } \\
\text { (Test Statistic) }\end{array}$ & Significance & $\begin{array}{c}\eta^{2} \\
\text { (Effect Size) }\end{array}$ \\
\hline Corrected Model & $2393.219 \mathrm{a}$ & 4 & 598.305 & 45.209 & 0.000 & 0.660 \\
\hline & 1046.067 & 1 & 1046.067 & 79.043 & 0.000 & 0.459 \\
\hline Pre-test & 22.106 & 1 & 22.106 & 1.670 & 0.199 & 0.018 \\
\hline Group & 1486.189 & 1 & 1486.189 & 112.299 & 0.000 & 0.547 \\
\hline Subject & 3.597 & 1 & 3.597 & 0.272 & 0.603 & 0.003 \\
\hline Group * Subject & 2.470 & 1 & 2.470 & 0.187 & 0.667 & 0.002 \\
\hline Error & 1230.781 & 93 & 13.234 & & & \\
\hline Total & 51674.000 & 98 & & & & \\
\hline Corrected Total & 3624.000 & 97 & & & & \\
\hline
\end{tabular}

a. $\mathrm{R}$ Squared $=0.660$ (Adjusted $\mathrm{R}$ Squared $=0.646$ )

Table 8. Tests of Between-Subjects Effects 
In addressing the first research question, "Is there any statistical difference between the academic attainment of students taught science using practical activity and those taught using traditional teaching method?", and testing its related hypothesis, "There is no significant difference between the academic attainment of science students taught using practical activities and those taught using traditional teaching method", the results showed a significant difference between the academic attainment of students taught science using practical activities and those taught using the traditional teaching method (Table 7 and Table 8).

The ANCOVA results showed a significant difference between the academic attainment of students taught science using practical activities and those taught using traditional expository/lecture ( $\mathrm{F}=89.733$, $\left.\mathrm{p}=0.000, \eta^{2}=0.496\right)$. This outcome indicates that there is a highly significant effect of practical work; the effect size is moderate, and accordingly, the hypothesis was rejected.

Regarding the second and third research questions:

- Is there any statistical difference between the academic attainment of chemistry and biology students taught using practical activities?

- Is there any statistical difference between the academic attainment of chemistry and biology students taught using traditional expository/lecture?

The ANCOVA results (Table 7) showed that there is no significant group-subject interaction effect $\left(\mathrm{F}=0.420, \mathrm{p}=0.519, \eta^{2}=0.005\right)$. This means that performance of students in biology and chemistry is consistent within control and experimental groups. Therefore, the hypothesis is not rejected.

\subsection{Discussion and Conclusion}

The results of our research show that there is a positive correlation between practical work and the academic attainment of most students in science. The findings are directly in line with previous studies' findings such as a study by Abdi (2014), which stated that the experimental groups had a much greater understanding of the information covered, especially regarding questions that required interpretation. Teachers were advised to consider how to prepare learning environments in which students will be more active and then present these environments to students.

In fact, other research has generated similar results. For example, Hofstein and Lunetta (1982) and Hofstein and Mamlok-Naaman (2007) mentioned that laboratory work plays an important role in science education and also helps in understanding the difference between observation and presentation of data. Hodson (1990) considered that practical work can motivate students and stimulate their interest in teaching and learning.

On the other hand, Boyuk et. al. (2010) and Ayogdu (1999) put forward that some teachers have reservations in regard to laboratory work. They mentioned that laboratory work is vital for studying sciences but there are certain problems encountered such as the lack of materials needed for the required experiment, insufficient information for carrying out the experiment, the techniques followed during the experiment, the glassware and the chemicals needed for the experiment, safety rules, what steps need to be followed to avoid any accident during the experiment, and finally what should be done in case of an accident during the experiment.

The researchers of the current study acknowledge the importance of these limitations and recommend that they must be studied and addressed by teachers and school administrators in order to allow the value of practical work to benefit students in achieving higher academic standards.

The researchers recommend that practical work is provided for most of the concepts in chemistry and biology, as they are considered an applied science. Some concepts cannot be understood if not applied practically. In addition to this, some concepts cannot be applied, thus, more research is needed to simplify science concepts in general, and make chemistry and biology easier and more exciting subjects in 
particular. This can help students become motivated, work harder and understand chemistry and biology better.

Therefore, the researchers suggest that further studies be undertaken to explore the role of using Information and Communication Technology (ICT) in teaching and learning science, perhaps in a way that would explain experiments that are difficult to be completed practically in the lab. To ensure the success of practical work, the researchers recommend that the administration of schools supply their schools with all necessary equipment, glassware, and chemicals needed to facilitate the practical work for most topics in chemistry and biology.

Finally, the researchers find it vital to allow students to design some of their own experiments (studentcentered activity) as this ensures they do not just follow instructions from teachers. Teacher-centered instruction can be boring for students and can affect the benefits of practical work, thus the researchers recommend that further studies examine the impact of this method on the efficacy of practical work.

\subsection{Limitations of Study}

The study was limited to two private schools and two science subjects (chemistry and biology). In addition, the researchers did not have the freedom to choose what was to be taught but had to follow the outline of the subjects' curriculum provided by the school. The number of lessons per week also had to be limited to what was scheduled and planned by the school. It may suffer from factors such as being too population-specific.

\subsection{Compliance with Ethical Standards}

All procedures performed in studies involving human participants should be in compliance with the ethical standards of the institution, the national research committee, and the 1964 Helsinki declaration and its later amendments or comparable ethical standards. Thus, the researchers ensured they obtained consent from Al Dhafra Private School and Sheikh Zayed Private Academy administrations to conduct this experimental study on the assigned students. Also, the consent of all the individual participants included in the study was obtained. Moreover, the study was conducted in compliance with the national ethical guidelines of the Ministry of Education research committee.

\section{Acknowledgements}

The researchers would like to extend special acknowledgment to Omaymah Qeis, Wisam Trabilsi and Leen Mahmoud for their contribution towards the data collection component of the research, which helped support the overall manuscript. Your time and efforts are greatly appreciated.

\section{Declaration of Conflicting Interests}

The authors declared no potential conflicts of interest with respect to the research, authorship, and/or publication of this article.

\section{Funding}

The authors received no financial support for the research, authorship, and/or publication of this article.

\section{References}

Abdi, A. (2014). The Effect of Inquiry-based Learning Method on Students' Academic Achievement in Science Course. Universal Journal of Educational Research, [Online] 2(1), 37-41. Available from: https://doi.org/10.13189/ujer.2014.020104 (Accessed: 15 March 2019).

Abrahams, I., \& Millar, R. (2008). Does practical work really work? A study of the effectiveness of practical work as a teaching and learning method in school science. International Journal of Science Education, 30(14), 1945-1969. https://doi.org/10.1080/09500690701749305 
Anderson, H.M (n.d). Dale's Cone of Experience [Online]. Available from: http://www.queensu.ca/teachingandlearning/modules/active/documents/Dales Cone of Experience summary. pdf (Accessed: 15th March 2019).

Aydogdu, C. (2015). Science and technology teachers' views about the causes of laboratory accidents. International Journal of Progressive Education, 11(3), 106-120.

Birk, J.P., \& Foster, J. (1993). The importance of lecture in general chemistry course performance. Journal of Chemical Education, 70, 180-182. https://doi.org/10.1021/ed070p180

Boyuk, U., Demir, S., \& Erol, M. (2010). Analyzing the proficiency views of science and Technology teachers on laboratory studies in terms of different variables. TUBAV Bilim Dergisi, 3(4),. 342-349.

Brooks, J.G., \& Brooks, M. (1999). In Search of Understanding: The Case for Constructivist.

Bryson, K.M.N., Millar, H., Joseph, A. \& Mobolurin, A. (2002). Using formal MS/OR modeling to support disaster recovery planning. European Journal of Operational Research, 141(3), 679-688. https://doi.org/10.1016/S0377-2217(01)00275-2

Campbell, D.T., \& Stanley, J.C. (1963). Experimental and quasi-experimental designs for research. Chicago: Rand McNally \& Company.

Cobb, P., McClain, K., de Silva Lamberg, T., \& Dean, C. (2003). Situating teachers' instructional practices in the institutional setting of the school and district. Educational Researcher. 32(6), 13-24. https://doi.org/10.3102/0013189X032006013

Dale, E. (1969). Audiovisual Methods in Teaching. New York: Dryden Press.

Dillon, J. (2008). A review of the research on practical work in school science [Online]. Available from: http://www.score-education.org/media/3671/review of research.pdf (Accessed: 28th Spril 2019).

Fadzil, H.M., \& Saat, R.M. (2013). Phenomenographic study of students' manipulative skills during transition from primary to secondary school. Sains Humanika, 63(2), 71-75.

https://doi.org/10.11113/jt.v63.2013

Hinneh, J.T. (2017). Attitude towards Practical Work and Students' Achievement in Biology: A Case of a Private Senior Secondary School in Gaborone, Botswana. IOSR Journal of Mathematics (IOSR-JM), 13(4), 06-11.

Hodson, D. (1990). A critical look at practical work in school science. School Science Review, 70(256), 33-40.

Hodson, D. (1991). Practical work in science: time for a reappraisal. Studies in Science Education, 19(1), 175-84. https://doi.org/10.1080/03057269108559998

Hofstein, A., \& Lunetta, V.N. (1982). The role of the laboratory in science teaching: Neglected aspects of research. Review of Educational Research, 52(2), 201-217. https://doi.org/10.3102/00346543052002201

Hofstein, A., \& Mamlok-Naaman, R. (2007). The laboratory in science education: the state of the art. Chemistry Education Research and Practice, 8(2), 105-107. https://doi.org/10.1039/B7RP90003A

Jakeways, R. (1986). Assessment of A-level physics (Nuffield) investigations. Physics Education, 21(4), 212. https://doi.org/10.1088/0031-9120/21/4/003

Jokiranta, K. (2014). The Effectiveness of Practical work in Science Education. Bachelor's Thesis. Available from: https://ivx.jyu.fi/dspace/bitstream/handle/123456789/42979/URN:NBN:fi:jyu-201402181251.pdf?sequence=1 (Accessed: 20 March 2019).

Lawson, A.E. (1995). Science teaching and the development of thinking. Wadsworth Publishing Company. 
Linn, M.C., Davis, E.A., \& Bell, P. (eds.) (2004). Internet environments for science education. Mahwah, NJ: Lawrence Erlbaum Associates.

Madhuri, G.V., Kantamreddi, V.S.S.N., \& Prakash Goteti, L.N.S. (2012). Promoting higher order thinking skills using inquiry-based learning. European Journal of Engineering Education, 37(2), 117-123. https://doi.org/10.1080/03043797.2012.661701

McKnight, K., Yarbro, J., Graybeal, L., \& Graybeal, J. (2016). United Arab Emirates: What makes an effective teacher? [Online]. Available from: https://www.pearson.com/content/dam/corporate/global/pearson-dotcom/files/innovation/globalsurvev/reports/RINVN11137 UAE report $f$ crops 091116.pdf (Accessed: 27 th April 2019).

Millar, R. (2004). The role of practical work in the teaching and learning of science [Online]. Available from: https://sites.nationalacademies.org/cs/groups/dbassesite/documents/webpage/dbasse 073330.pdf (Accessed: 27th March 2019).

Okam, C.C., \& Zakari, I.I. (2017) Impact of Laboratory-Based Teaching Strategy on Students' Attitudes and Mastery of Chemistry in Katsina Metropolis, Katsina State, Nigeria. International Journal of Innovative Research and Development, 6(1), 112.

Osborne, J. (1993). Alternatives To Practical Work. School Science Review, 75(271), 117-123.

Piaget, J. (2013). The construction of reality in the child. UK: Routledge \& Kegan Paul. https://doi.org/10.4324/9781315009650

Price, P., Jhangiani, R., \& Chiang, I.A. (2015). Research methods in psychology (2nd ed.). Washington D.C: Saylor.org

Roberts, A. (2008). Practical Work in Primary School [Online]. Available from: http://www.scoreeducation.org/downloads/practical_work/primary.pdf (Accessed: 27th April 2019).

Russell, C.B., \& Weaver, G.C. (2011). A comparative study of traditional, inquiry-based, and research-based laboratory curricula: impacts on understanding of the nature of science. Chemistry Education Research and Practice, 12(1),. 57-67. https://doi.org/10.1039/C1RP90008K

Sandi-Urena, S., Cooper, M.M., Gatlin, T.A., \& Bhattacharyya, G. (2011). Students' experience in a general chemistry cooperative problem based laboratory. Chemistry Education Research and Practice, 12(4),. 434-442. https://doi.org/10.1039/C1RP90047A

Singer, S.R., Hilton, M.L., \& Schweingruber, H.A. (2006). America's Lab Report: Investigations in High School Science. Washington, DC: The National Academies Press.

Solomon, J. (1999). Envisionment in practical work. Helping pupils to imagine concepts while carrying out experiments. In J. Leach and A. Paulsen (eds.). Practical work in science education: Recent research studies, 60-74. The Netherlands: Roskilde University Press/ Kluwer.

Sotiriou, S., Bybee, R.W., \& Bogner, F.X. (2017). PATHWAYS-A Case of Large-Scale Implementation of Evidence-Based Practice in Scientific Inquiry-Based Science Education. International Journal of Higher Education, 6(2), 8-19. https://doi.org/10.5430/ijhe.v6n2p8

Sunal, C.S., Smith, C., Sunal, D.W., \& Britt, J. (1998). Using the Internet to create meaningful instruction. The Social Studies, 89(1), 13-17. https://doi.org/10.1080/00377999809599816

Schwichow, M., Zimmerman, C., Croker, S., \& Härtig, H. (2016). What students learn from hands-on activities? Journal of Research in Science Teacbing. Advance online publication.

https://doi.org/10.1002/tea.21320 
Tobin, K. (1990). Research on science laboratory activities: In pursuit of better questions and answers to improve learning. School science and Mathematics, 90(5), 403-418. https://doi.org/10.1111/j.19498594.1990.tb17229.x

Tsakeni, M. (2018). Inquiry-Based Practical Work in Physical Sciences: Equitable Access and Social Justice Issues. Issues in Educational Research, 28(1), 187-201.

UAE Vision 2021 (n.d). UAE Vision 2021: Building a Knowledge Economy [Online]. Available from: https://www.vision2021.ae/en/national-agenda-2021 (Accessed: 26th April 2019).

White, H., \& Sabarwal, S. (2014). Quasi-experimental design and methods, Methodological Briefs: Impact Evaluation 8 [Online]. Available from: https://www.unicef-irc.org/KM/IE/img/downloads/quasiexperimental design and methods ENG.pdf (Accessed: 15th March 2019).

Woolnough, B.E. (1994). Effective Science Teaching. Developing Science and Technology Education. Bristol: Open University Press.

Woolnough, B.E., \& Allsop, T. (1985). Practical work in science. Cambridge: Cambridge University Press.

Yore, L.D. (2001). What is meant by constructivist science teaching and will the science education community stay the course for meaningful reform. Electronic Journal of Science Education, 5(4), 1-7.

Zhenhui, R. (2001). Matching teaching styles with learning styles in East Asian contexts. The Internet TESL Journal, 7(7), 5.

Published by OmniaScience (www.omniascience.com)

Journal of Technology and Science Education, 2020 (www.jotse.org)

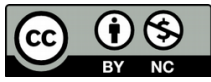

Article's contents are provided on an Attribution-Non Commercial 4.0 Creative commons International License.

Readers are allowed to copy, distribute and communicate article's contents, provided the author's and JOTSE

journal's names are included. It must not be used for commercial purposes. To see the complete licence contents, please visit https://creativecommons.org/licenses/by-nc/4.0/. 